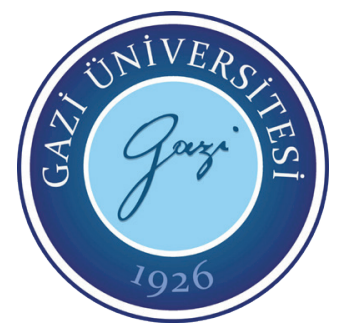

\title{
YAŞAM KALITESI VE \\ WELLNESS
}

Prof. Dr. Erdal ZORBA 


\section{(C) Copyright 2021}

Bu kitabın, basım, yayın ve satış hakları Akademisyen Kitabevi A.Ş.'ne aittir. Anılan kuruluşun izni alınmadan kitabın tümü ya da bölümleri mekanik, elektronik, fotokopi, manyetik kağıt ve/veya başka yöntemlerle çoğaltılamaz, basılamaz, dağıtılamaz. Tablo, şekil ve grafikler izin alınmadan, ticari amaçh kullanılamaz. Bu kitap T.C. Kültür Bakanlı̆̆ı bandrolü ile satılmaktadır.

\section{ISBN}

978-625-7496-03-2

\section{Kitap Adı}

Yaşam Kalitesi ve Wellness

Yazar

Erdal ZORBA

ORCID iD: 0000-0001-7861-8204

\section{Editörler}

Akan BAYRAKDAR

ORCID iD: 0000-0002-3217-0253

Mehmet YILDIZ

ORCID iD: 0000-0001-9784-6050

\section{Yayın Koordinatörü Yasin DİLMEN}

\section{Sayfa ve Kapak Tasarımı} Akademisyen Dizgi Ünitesi

\section{Yayıncı Sertifika No}

47518

Baskı ve Cilt

Göktuğ Ofset

Bisac Code

HEA000000

DOI

10.37609/akya.557

\section{GENEL DAĞITIM Akademisyen Kitabevi A.Ş.}

Halk Sokak 5 / A

Yenişehir / Ankara

Tel: o312 4311633

siparis@akademisyen.com 


\section{ÖN SÖZ}

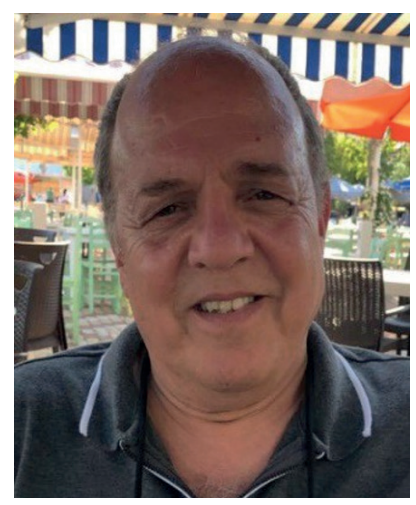

Sağlık; hayat tarzınızla ve davranışlarınızla etkilediğiniz, çevrenizle çok sıkı bir ilişki halindedir. $\mathrm{Bu}$ nedenledir ki zaman içerisinde davranışlarınız ve yaşantınızda meydana gelen değişiklikler, sağlık konusunda çok yeni boyutların oluşmasına sebep olmuştur.

Son yilların en popüler sözlerinden biri de $W E L L-$ NESS kelimesi olmuştur. Wellness faaliyetleri Türkiye'de ilk olarak 2008 yllında Herkes İçin Spor (HİS) Federasyonu'nun bünyesinde antrenörlük belgesi verilmesi ile başlatılmıştır. Bu kitabın hazırlanmasına aynı tarihte başlanmış, 2013 yılında bitmesine rağmen bu yıla kadar eklemelere devam edilmiştir. Wellness antrenörlüğünden sonra Yoga antrenörlük eğitim faaliyetlerine de aynı federasyon bünyesinde başlanmıştır. İlerleyen yıllarda bu branşlar, üniversitelerin Spor Bilimleri Fakültelerinde ders olarak konulmuştur.

Her canlı gibi insan için de şüphesiz yaşlanma kaçınılmaz bir süreçtir. Ancak bu yaşlanmayı yavaşlatmak, daha zinde, sağlıklı ve mutlu bir hayatı sürdürebilmek çoğunlukla elimizdedir.

İnsanlık tarihinde yüzyıllar boyunca sağlıklı olmak, yaşlanmayı yavaşlatmak, enerjik, canlı ve pozitif olabilmek için araştırmalar yapılmıştır Doğumla başlayan biyolojik gelişmede; psikolojik olumsuzluklara karşı dirençli olmak, sağlıklı çevrede yaşamak, doğru beslenmek, hareketli olmak, stresle başa çıkabilmek, hayata pozitif bakabilmek, hoş görülü olabilmek gibi elimizde olan faktörleri kontrol altına alarak sağlıklı ve uzun yaşamın temel anahtarına sahip olabiliriz. Böylece genetik faktörlerimizde olabilecek olumsuzlukların etkisini de en alt seviyeye düşürebiliriz.

Dünyada sağlıklı ve uzun yaşayan insanları inceleyen bilim insanları, hepsinde ortak özellikler olarak şunları bulmuşlardır: ${ }^{*}$ Ömür boyu çalışma, ${ }^{*}$ Ölene kadar hareketli ve neşeli bir hayat tarzı benimseme, ${ }^{*}$ Beslenmeye dikkat etme (doğal ve yaşa bağlı Akdeniz mutfağını tercih etme), sosyal diyalogları canlı ve diri tutma, yeni şeyler öğrenmeye gayret etme, düzenli uyuma, hayata hep pozitif bakabilme, bulunduğunuz çevrenin büyüğe saygılı itbarlı olması, inançlı olmak ve biraz da şansın olması gerektiğini vurgulamıştır. 
Hipokrat asırlar önce bu konulara değinmiş ve ve "Ĕger biz; her ferde, ne çok az ne de çok fazla, doğru miktarda gıda ve hareket (spor) verebilseydik, sağlık için en güvenli yolu bulurduk.” demiştir. Hipokrat iç organlarımızın önemine de değinerek; "Bütün hastalıklar bağırsakta başlar. Bağırsak hasta ise vücudun geri kısmı da hastadır.” diyerek să̆lığın anahtarını yüzyıllar önce özetlemiştir.

Büyük Türk alimi İbn-i Sina da "Sağlı̆̆ı korumanın üç temel prensibi vardır: hareket (spor), gıda ve uyku.” sözleriyle sağhılı yaşamın ana hatlarını Hipokrat gibi özetlemiştir.

Bütün bu kavramları; "Yaşam Kalitesi ve Wellness" kelimesiyle bütünleştirebiliriz ve kitabın ilerleyen bölümlerinde detaylı olarak da ele alacağız.

Bu kitapta; Wellnes, yaşam kalitesi, sağlıklı yaşam ve egzersiz, uykunun yaşam kalitesindeki rolü, bağırsak ve ağız floralarının (mikrobiyotaların) önemi, fiziksel uygunluk, davranış ve kendini yönetme becerisi, iş verimliliği ve fiziksel aktivite, 65 yaş üstü bireylere uzun yaşamak için davranış değişiklikleri ve Wellness, stresle başa çıkma, iş yeri egzersileri ve Wellness, beslenme alışkanlıkları, obezite ve vücut yağ ölçümleri ile son olarak Wellness amaçlı hareket edebilmeve egzersiz çeşitlerinin uygulamaları anlatılmıştır.

Kısaca bu kitabın amac1, 3’ten 93'e herkesin yararlanabileceği, sağliklı yaşlanma, sağlıklı yaşam ve Wellness felsefesini oluşturmaktır.

$\mathrm{Bu}$ çalışmada emeği olan araştırmacılara, yazarlara, eleştirileri ile katkı veren meslektaşlarıma ve bunu yaşam felsefesi haline getirenlere teşekkür ederim.

3’ten 93'e tüm insanların sağlıklı yaşamasına katkı sağlayacă̆ı UMUDU ile ...

Prof.Dr. Erdal ZORBA

Gazi Üniversitesi 


\section{TAKDIM}

Bireysel ve toplumsal katkılarıla birlikte spor bireyden başlayarak toplumun her kesimini toplayan, birleştiren sağlıklı bir toplum olmasındaki önemi her geçen gün daha fazla artan bir alandır. Hayat tarzımıza, davranışımıza ve genetikten gelen mirasımıza etki eden spor, çevremizle de çok sıkı bir ilişki halindedir. $\mathrm{Bu}$ nedenledir ki spor, zaman içerisinde davranışlarınızda ve yaşantınızda önemli değişiklikler olması beklenebilir. Bireye sadece bedensel değil ruhsal, sosyal, entelektüel, aile ve millet anlayışına olumlu kazançlar sağlamaktadır. Spor, bu kazançların yanında yaşam kalitemizi yükseltecek, sağlıklı ve uzun ömürlü olmada doğunun ve inançların ruhani bütünlüğü ile batının gelişmiş demogafik anlayışını harmanlayarak yaşam kalitesine boyut kazandırılmaya çalışılmış bir kitap olma özelliğini taşımaktadır.

$\mathrm{Bu}$ nedenle sporu, hayatın her alanına yayarak günlük yaşantımızda, yaşam felsefemize katkı vereceğine inandığımız için her yaşa ve cinsiyete hitap edecek şekilde düzenlenmelidir.

Son yıllarda teknolojinin gelişmesi ve dünyayı derinden sarsan Corona-19 salgınıyla birlikte hareketsiz bir hayatın getirdiği hastalıkları hepimiz biliyoruz. 30 yıldır dilimizden düşürmediğimiz aşırı kilo, yüksek tansiyon, kalp rahatsızlıkları, bağışıklı sisteminin zayıflaması ve kanser gibi fizyolojik rahatsızlıklardan, da bahsedebiliriz. Ayrıca sosyal iletişim, beslenme, uyku bozuklukları, hayata olumlu ve mutlu bakamama, inanç kavramlarındaki zayıflık da hareketsizlik gibi bireyden başlayarak toplumun her kesimini etkilemiş durumdadır.

Sağlıklı birey ve toplumun oluşmasında, huzurlu ve mutlu yaşlanmayı da bilmek gerekir. Her canlı gibi insan için de şüphesiz yaşlanma kaçınılmaz bir süreçtir. Ancak bu yaşlanmayı yavaşlatmak, daha zinde, sağlıklı ve mutlu bir hayatı sürdürebilmek çoğunlukla elimizdedir. Doğumla başlayan biyolojik gelişmede; psikolojik olumsuzluklara karşı dirençli olmak, sağlıklı çevrede yaşamak, doğru beslenmek, hareketli olmak, stresle başa çıkabilmek, hayata pozitif bakabilmek, hoşgörülü olabilmek, inanmak ve inançlı olmak gibi elimizde olan faktörleri kontrol altına alarak sağlıklı ve uzun hayatın temel anahtarına sahip olabiliriz. Böylece genetik faktörlerimizde olabilecek olumsuzlukların etkisini de minimum seviyeye düşürebiliriz.

İster uzun, ister kısa bir hayatları olsun, sağlıklı, mutlu olmuş ve hala yaptıklarından bahsedilen tarihte örneklerimiz vardır. Örneğin Ahmet Yesevi, Mimar 
Sinan, hâlâ dünya tıp camiasında deha olarak bahsedilen İbn-i Sina Hacı Bektaş-1 Veli, Yunus Emre, Mevlana gibi ismini sayamadığımız gönüllerde genç kalan rehberlerimiz var. Çünkü "Gençlik hayatın belli bir çağı ile ilgili değildir: İnsan, kendine olan güveni derecesinde genç, şüphesi derecesinde yaşlıdır; Cesareti derecesinde genç, korkuları derecesinde yaşlddr: Ümitleri derecesinde genç, ümitsizliği derecesinde yaşlıdır."

Gazi Üniversitesinin destekleri ve Gazi Üniversitesi Sporda Yetenek ve Performans uygulama ve Araştırma merkezinin çalışmalarıyla basılan bu kitabın; insanlığa, bilime, sağlkkl bir toplum oluşturmasına katı sağlaması dileğiyle emeği geçen herkese teșekkür ederim.

Prof. Dr. Musa YILDIZ

Gazi Üniversitesi Rektörü 


\section{" HAYATTA EN BÜYÜK YATIRIM INNSANA YAPILAN YATIRIMDIR. INSANI YAŞAT KI YAŞAYASIN, YAŞATMADAN YAŞAYAMAZSIN. "}

"Açık ve kat'i olarak söyleyeyim ki, sporda muvaffak olabilmek için her türlü yardımdan ziyade, bütün milletçe sporun mahiyetinin ve değerinin anlaşılmış olması gerekmekte, onu kalpte muhabbet ve vatanî bir vazife olarak telakki eylemek lazımdır."

Mustafa Kemal ATATÜRK

"Eğer biz her ferde, ne çok az, ne de çok fazla, doğru miktarda gıda ve hareket (spor) verebilseydik, sağllk için en güvenli yolu bulurduk."

Hipokrat

"Sağhlğı korumanın üç temel prensibi vardır: hareket (spor), gıda ve uyku."

İbn-i Sina 
- 


\section{IÇINDEKILER}

1. Bölüm Sağlıklı Yașam ve Egzersiz ....................................................... 1

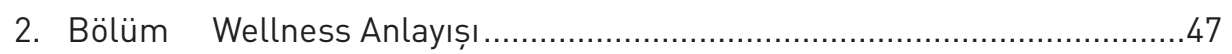

3. Bölüm Fiziksel Uygunluk Yașam Kalitesi ve Wellness ..............................65

4. Bölüm Yașam Kalitesi ve Wellness Kavramında Kendini

5. Bölüm Fiziksel Uygunluk ve Wellness İçin Egzersiz Düzeyleri ...............105

6. Bölüm Yașam Boyu Wellness Olgularının Keșfi......................................123

7. Bölüm İ̦ Verimliliği Wellness ve Egzersizler ........................................139

8. Bölüm Wellness ve Stresle Bașa Çıkma ..............................................165

9. Bölüm Yașlılarda Fiziksel Aktivite Fiziksel Uygunluk ve Wellness..........185

10. Bölüm Sağlık İçin Beslenme ve Wellness.............................................245

11. Bölüm Obezite,Șismanlik, Kilo Kontrolü ve Wellness ............................289

12. Bölüm Wellness Uygulamaları I ............................................................351

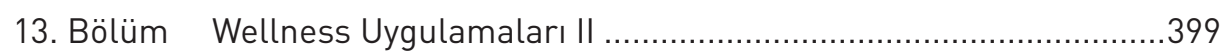

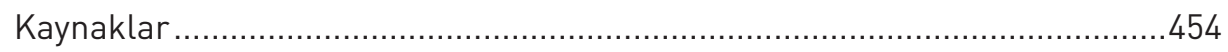


- 


\section{KAYNAKLAR}

ACSM (Ed.), A. C. of S. M. (2013). ACSM's health-related physical fitness assessment manual (4th ed.). Lippincott Williams \& Wilkins.

Adler, A., \& Seligman, M. E. (2016). Using wellbeing for public policy: Theory, measurement, and recommendations. International Journal of Wellbeing, 6(1). https://doi.org/10.5502/ijw.v6i1.429.

Ağız probiyotiği. (2018). Erişim adresi: http://www.prolacsan.com.tr/agiz- kokusu-ve- agiz-probiyotigi/agiz-probiyotigi

Ağız sağlı̆̆ı ve kalp hastalıkları arasında ilişki. (2018). Erişim adresi:https://www.colgate.com/tr-tr/ oral-

health/conditions/heart-disease/how-oral-health-and-heart-disease-are-connected-0115.

Akandere, M., (1993), 17- 22 yaş grubu kız sporcularının esnekliklerinin geliştirmesi. Selçuk Üni. Konya.

Akgün, N., (1989), "Egzersiz Fizyolojisi," Gökçe Matbaası, Ankara.

Akın, G. (2000). Her Yönüyle Yaşlilık (Gerontoloji). Ankara, Palme Yayıncıllk

American Collage of Sport Medicine, (1999), Guidelines for graded exercise testing and exercise prescription, Second Ed., Lea And Febiger, Philadelphia.

Alters, S., \& Schiff, W. (2003). Essential Concepts for Healthy Living. Jones and Barlett Publisher.

Altuntaş,Y. ve Batman, A. (2017). Mikrobiyota ve metabolik sendrom. Turk Kardiyol Dern Ars, 45(3), 286-296.

American Heart Association (1983), An Older Person's Guide to Cardiovascular Health" Dallas. AHA.

Anderson, B. (Çev: Yaman, M., Coşkuntürk S, O., Hergüner, G. (1993). Stretching.

Kilıçaslan Matbaacılık.

Anderson, J., \& M. Ed. C. S.C. S. (2018). Atletik performans geliştirme (sportif performansı geliştirme için uygulamal bir kılavuz). Spor Yayınevi ve Kitapevi.

Anderson, D., Morris, T. (2000). Athlete lifestyle programs. In: Lavallee D, Wylleman P, editors. Career transitions in sport: international perspectives. Morgantown: Fitness Information Technology. 59-80.

Anthoine, E., Moret, L., Regnault, A., Sébille, V., \& Hardouin, J. B. (2014). Sample size used to validate a scale: a review of publications on newly-developed patient reported outcomes measures. Health and Quality of Life Outcomes, 12(1), 1-10. https://doi.org/10.1186/s1295 5-014-0176-2.

Arnold, R., \& Fletcher, D. (2012). A research synthesis and taxonomic classification of the organizational stressors encountered by sport performers. Journal of Sport ond Exercise Psychology, 34(3), 397-429. https:// doi.org/10.1123/jsep.34.3.397.

Aslan, M., \& Hocaoğlu, Ç. (2017). Yaşlanma ve yaşlanma dönemiyle ilişkili psikiyatrik sorunlar. Düzce Üniversitesi Sağllk Bilimleri Enstiüsü Dergisi, 7(1), 53-62.

Atabek, H.Ç. (2011) Exercise and oxidative stress: The effects of resistance exercise: Review. Turkiye Klinikleri Journal of Sports Sciences, 3 (2), 92.

Atlı K., Bozcuk N., Telomer ve Hücresel Yaşlanma. Turkish Journal of Geriatrics. (2002) 5 (3): 111114.

Astrand, P. O., \& Rodahl, K. (1986). Textbook of work physiology (The McGraw- hill series in health education, physical education, \& Recreation (2th ed.). McGraw-Hill Book Co.

Aydın Z. D. (2006). Toplum ve birey için sağlıkl yaşlanma, yaşam biçiminin rolü. Süleyman Demirel Üniversitesi Tip Fakültesi Dergisi. 13(4), 43-48.

Bale, P. (1985). Relationship among physique, strength, and performance of students. Journal of Sport Medicine, 25, 175-213.

Baumgartner, T. A., Andrew, S.J., (1975). Measurement for evaluation in physical education. London: Houghton Mifflin Company, 175-213. Cardiovascular Health" Dallas, AHA.

Barry H. C. (1994). Eathorne SW. Exercise and aging issues fort he practitioner. Med Clin North Am. 78(2), 357-376. 
Başkan, H., A. (2020). Sporcu ve sedanter bireylerin ağız mikrobiyotasındaki bazı bakterlerin incelenmes. Doktora tezi, Gazi Üniversitesi Sağllk Bilimleri Enstitüsü, Ankara.

Baysal, A. (1990). Beslenme (4. Baskı). Ankara: Hacettepe Üniversitesi Yayınları.

Benson, H., \& Stuart, E. M. (1993). The Wellness book: The comprehensive guide to maintaining health and treating stress-related illness (S. A. Schuster (Ed.).

Benson, H., \& Stuart, E. M. (1993). The Wellness book: The comprehensive guide to maintaining health and treating stress-related illness. Simon and Schuster. ??? (1998). Beslenme Rehberi. Ankara: Hacettepe Yayinları,

Bilir N. (2005). Yaşlllarda sağlık taramaları. içinde: yaşllar ve belediyeler. (Ed): G. Y. Kutsal Ankara: I. Aygül Ofset.

Booth, T., Hughes, D. J. (2014). Exploratory structural equation modeling of personality data. Assessment, 21(3), 260-271. https://doi. org/10.1177/1073191114528029.

Bouchard, C., Tremblay, A., Després, J.-P., Nadeau, A., Lupien, P. J., Thériault, G., ... Fournier, G. (1990). The response to long-term overfeeding in identical twins. New England Journal of Medicine, 322 (21), 1477-1482. http://doi.org/10.1056/NEJM199005243222101

Bray, G. A. (1969). Effect of caloric restriction on energy expenditure in obese patients. Lancet (London, England), 2 (7617), 397-8. Retrieved from http://www.ncbi.nlm.nih.gov/pubmed/4184486

Brent, A., \& Sharon, P. (2008). Healthy aging for dummies (I. John Wiley \& Sons (Ed.)).

Campos, P., Saguy, A., Ernsberger, P., Oliver, E., \& Gaesser, G. (2006). The epidemiology of overweight and obesity: Public health crisis or moral panic? International Journal of Epidemiology, 35(1), 55-60. http://doi.org/10.1093/ije/dyi254.

Cardinale, M., Newton, R., \& Nosaka, K. (2011). Strength and Conditioning - Biological Principles and Practical Applications (M. Cardinale, R. Newton, \& K. Nosaka Eds. First ed.). UK: A John Wiley \& Sons, Ltd.,Publication.

Ceyhan, S. (2005). Kayser Nuh Naci Yazgan Sağllk Ocağı bölgesinde yaşayan 65 ve üstü bireylerin yalnızlık düzeylerinin incelenmesi, Yüksek lisans tezi Erciyes Üniversitesi Sağllk Bilimleri Enstitüsü, Kayseri.Chen, M. (1999). The effectivenes of health promotion counseling to family caregivers. Public Health Nursing. 16(2),125-132.

Colley, R. C., Garriguet, D., Janssen, I., Craig, C. L., Clarke, J., \& Tremblay, M. S. (2011). Physical activity of Canadian children and youth: accelerometer results from the 2007 to 2009 Canadian Health Measures Survey. In Health reports (Vol. 22, Issue 1). https://doi.org/82-003-XPE

Cooper, K. H. (1986). A means of assessing maksimal oxygen intake, Journal of American Heart Association, 135-203.

Corbin, C., \& Lindsey, R. (2007). Fitness for Life (5th ed.). Human Kinetics.

Corbin, C., Welk, G., Corbin, W., \& Welk, K. (2010). Concepts of physical fitness: Active lifestyles for Wellness (16th Editi). McGraw-Hill Education.

Corbin, C., Welk, G., Corbin, W., \& Welk, K. (2011). Concept of fitness and Wellness. McGraw-Hill Compaines.

Corbin, C., Welk, G., Corbin, W., \& Welk, K. (2019). Concepts of fitness and Wellness: A comprehensive lifestyle approach (12th ed.). McGraw-Hill Education.

Costil, D. L., Maglishco, E.W., Richardsson, A .B. (1992). Swimming, England: Blackwell Scientific Pub., 24-26.

Curioni, C. C., \& Lourenco, P. M. (2005). Long-term weight loss after diet and exercise: a systematic review. International Journal of Obesity, 29(10), 1168-1174. Cam O. ve Bilge A. (2007). Ruh hastalığına yönelik inanç ve tutumlar. Anadolu Psikiyatri Dergisi. 8, 215-223.

Çelik, A., Varol, R., Onat,T., Dağdelen, Y., Tugay, F. (2007) Akut egzersizin futbolcularda antioksidan sistem parametrelerine.

Çolakoğlu, F. F. (2003). Bayanlarda fizyolojik, motorik ve somatotip değerleri üzerine etkisi, Gazi Eğitim Fakültesi Dergisi, 23 (3), 275-290. 
Dalleck, L. C., Atwood, J. P., Prins, R. L., Buchanan, C. A., \& Curry, M. A. (2014). Developing a comprehensive exercise prescription: the optimal order for cardiorespiratory, resistance, flexibility, and neuromotor exercise. Journal of Fitness Research, 3(2), 13-25.

De Vries, H.A., (1972). Physiology of exercise for physical education and athletics, Iowa: WM.C. Brown Company Publishers, 254-255.

Diener, E., \& Tov, W. (2012). National accounts of well-being. In Handbook of social indicators and quality of life research (s. 137-157). Springer, Dordrecht.

Different States of Mind. Mind Motivation. Retrieved 24 July 2013.

Doğrul A. (2010). Alkol kullanımı ve intihar olasıliğının stresle başedebilme yöntemleri ile ilişkisinin incelenmesi. İstanbul Üniversitesi Adli Tip Enstitüsü, İstanbul.

Dolan, P., \& White, M. (2006). Dynamic well-being: Connecting indicators of what people anticipate with indicators of what they experience. Social Indicators Research, 75(2), 303-333. https://doi. org/10.1007/s1120 5- 004-6298-x.

Dolan, P., Peasgood, T., \& White, M. (2006). Review of research on the influences on personal well-being and application to policy making. London; DEFRA (http://www. defra. gov. uk/science/project_data/DocumentLibrary/SD12005/SD12005_4017_F RP. pdf).

Doll, B., \& Cummings, J. A. (2007). Transforming school mental health services: Population-based approaches to promoting the competency and Wellness of children. Corwin Press.

Ersoy, G., (1995). Sağlikl yaşam spor ve beslenme, Ankara: Damla Matbaası,.62-67.East, W., Frazier, J., Matney, L. (1989), Assessing the physical fitness of elementary school children, JOPERD, 5,54-56.

Ekenci, G., İmamoğlu F., (1998), Spor işletmeciliği, Ankara: Alp Ofset Matbaacılik.Erkan, N., (1998). yaşam boyu spor. Ankara: Spor KitabeviFain, G. (1979). Why employe recreation? Leisure Today, 32, 22-23.

Feuerstein, G. (2006). Yoga and meditation (Dhyana). Moksha Journal. Issue 1. 2006. ISSN 1051127X, OCLC 21878732

Feuerstein, G. (2006). Yoga and Meditation (Dhyana). Moksha Journal, 1, 1051-127X.

Fleck, S. J., \& Kraemer, W. J. (2014). Designing resistance training programs (Fourth edition ed.): Human Kinetics.

Fitness and Wellness by Wener W.K. Hoeger (Feb 18, 2010). Gen. Lamrimpa (author); "Calming the Mind." Snow Lion Publications. 1995. Book on Buddhist methods for developing single pointed concentration. Gen.Lamrimpa (author); "Calming the Mind." Snow Lion Publications. 1995. Includes basic instructions for analysis of reality.

Genç A, vd. (2018). ramazan orucunun yetişkin erkeklerde kan lipid parametreleri üzerine etkisi. Uluslararasl, Hakemli Akademik Spor Sağllk ve Tip Bilimleri Dergisi.

Genç A. (2018). Spor yapan ve yapmayan bireylerde bazı baskın bağırsak mikrobiyota türlerinin incelenmesi, Doktora tezi,"Gazi Üniversitesi Sağllk Bilimleri Enstitüsü, Ankara.Göksu, Ö. C., Harutoğlu, H., \& Yiğit, Z. (2003). Sedanter kişilere uygulanan 10 haftalik egzersiz programının fiziksel uygunluk ve kan parametrelerine etkisi. İ.Ü. Spor Bilimleri Dergisi, 11(3), 18-23.

Greenberg, J. S., \& Pargman, D. (1989). Physical fitness: A Wellness approach. Prentice Hall.

Gregory Welk, G., Corbin, W. and K. Welk (2010). Concepts of Physical Fitness: Active Lifestyles for Wellness by Charles Corbin, (Oct 21, 2010).

Gregory Welk, G., Corbin, W. and K. Welk (2010).

Güneş, Z. (1998). Sporda beslenme. Bagirgan Yayınları.

Guo, Yf., Liao, Mq., Cai, Wl. et al. (2021). Physical activity, screen exposure and sleep among students during the pandemic of COVID-19. Sci Rep, 11, 8529 Güllü, E., Tamer, K., Özer, Ç., Güllü, A., Cicioğlu, I. (???). Dayanıklılı sporcularında maksimal ve ubmaksimal egzersiz sonrası oluşan oksidan stres ve antioksidan düzeylerinin araşttrilmast.

Hamamcılar, O. (2009). 14-17 yaş grubu güreş ve boks branş sporcularının çürük prevalansı. BESBD, 4(4), 151-55. 
Hahn, P., \& Novak, M. (1975). Development of brown and white adipose tissue. Journal of Lipid Research, 16(2), 79-91.

Hardman, A. E., \& Stensel, D. J. (2009). Physical activity and health: the evidence explained (2th ed.). Routledge. Haslam, D., Sattar, N., \& Lean, M. (2006). Obesity -time to wake up. Bmj, 333 (7596), 640-642. https://doi.org/https://doi.org/10.1136/bmj.333.7569.640

Hardman, A. E., \& Stensel, D. J. (2009). Physical activity and health (2nd ed.). Taylor \& Francis Group.

Hellison, D. R. (1995). Teaching responsibility through physical activity. Teaching responsibility through physical activity. Human Kinetics.

Hendricks, G. (1995). Conscious breathing: breathwork for health, stress release, and personal mastery. Bantam.

Heyward, V. H. (2010). Advanced fitness assessment and exercise prescription (6th ed.). Human Kinetics.

Hill, J. O., \& Wyatt, H. R. (1999). Relapse in obesity treatment: biology or behavior? The American Journal of Clinical Nutrition, 69(6), 1064-1065. https://doi.org/https://doi.org/10.1093/ ajcn/69.6.1064

Hill, N. R. (2004). The challenges experienced by pretenured faculty members in counselor education: A Wellness perspective. Counselor Education and Supervision, 44(2), 135-146. https://doi. org/10.1002/j.1556- 6978.2004.tb01866.x

Hoeger, W. W., Hoeger, S. A., Hoeger, C. I., \& Fawson, A. L. (2012). Lifetime physical fitness and Wellness (15th ed.). Cengage Learning.

Howe, C. Z. (1983). Establishing employee recreation programs: a humane rationale. Journal of Physical Education, Recreation \& Dance, 54(8), 34-52. https://doi.org/https://doi.org/10.1080/07 303084.1983.10630531 https://www.ted.com/talks/matt_walker_sleep_is_your_superpower?languag $e=\operatorname{tr} 17.06 .202112 .52$

Satman, I \& TURDEP. (2010). TURDEP-II Sonuçlarl. İstanbul. Retrieved from http://www.turkendokrin.org/files/file/TURDEP_II_2011.pdf.

Ingram, J., Maciejewski, G. and Hand, C. J. (2020). Changes in diet, sleep, and physical activity are associated with differences in negative mood during COVID-19 Lockdown. Front. Psychol., 02 September 2020 |https://doi.org/10.3389/fpsyg.2020.588604

Irrez, G. (2003). Yaşları Arasında Bayanlarda 8 Haftalık Step Çalışmalarının Bazı Fizyolojik ve Antropometrik Parametrelerinin Etkisinin Araștırılması. Muğla Üniversitesi.

Jacobson, E. (1938). Progressive relaxation: A physiological and clinical investigation of muscular states and their significance in psychology and medical practice. Chicago: University of Chicago Press.

Jakicic, J. M., Winters, C., Lang, W., \& Wing, R. R. (1999). Effects of intermittent exercise and use of home exercise equipment on adherence, weight loss, and fitness in overweight women: a randomized trial. JAMA, 282(16), 1554-1560. https://doi.org/10.1001/jama.282.16.1554

James, W. P. (1995). A public health approach to the problem of obesity. International journal of obesity and related metabolic disorders. International Journal of Obesity and Related Metabolic Disorders: Journal of the International Association for the Study of Obesity, 19(3), 37-45.

Jeffery, R. W., \& Sherwood, N. E. (2008). Is the obesity epidemic exaggerated? BMJ (Clinical Research Ed.), 336(7638), 244-245. https://doi.org/http://doi.org/10.1136/bmj.39458.495127.AD

Jones, R., \& Randall, C. (2018). Measuring national well-being: Quality of life in the UK, 2018. ONS: Newport,UK.https://www.ons.gov.uk/peoplepopulationandcommunity/wellbeing/articles/measuringnationalwellbeing/qualityoflifeintheuk 2018. Accessed 09 Aug 2019.

Karaduman A. (2004). Fiziksel aktivite ve egzersiz. içinde: sağlıkl ve başarıl yaşlanma. (Ed.): GY Kutsal. Ankara: Hacettepe Üniversitesi Hastaneleri Basımevi.Karakoç A. (2006). Sinıf ögretmenlerinin sağlıklı yaşam biçimi davranışları ve bu davranışı etkileyen bazı faktörlerin belirlenmesi. Yüksek lisans tezi, Cumhuriyet Üniversitesi Sağlık Bilimleri Enstitüsü, Sivas. 
Karpay, E. (2000). The everything total fitness book. Adams Media Corporation.

Katch, F. (1988). Nutrition, Weight Control and Exercise (3rd ed.). Lea \& Febiger.

Klem, M., Wing, R., McGuire, M., Seagle, H. M., \& Hill, J. O. (1997). A descriptive study of individuals successful at long-term maintenance of substantial weight loss. The American Journal of Clinical Nutrition, 66, 239-246. https://doi.org/https://doi.org/10.1093/ajcn/66.2.239

Kraft, G. H., \& Catanzaro, M. (2000). Living with multiple sclerosis: a Wellness approach. Demos Medical Publishing.

Kriska, A. (1995). Physical activity and public health: a recommendation from the Centers for Disease Control and Prevention and the American College of Sports Medicine. Jama, 273(5), 402-407.

Lahti-Koski, M., Pietinen, P., Heliövaara, M., \& Vartiainen, E. (2002). Associations of body mass index and obesity with physical activity, food choices, alcohol intake, and smoking in the 19821997 FINRISK Studies. The American Journal of Clinical Nutrition, 75(5), 809-817. https://doi. org/10.1093/ajcn/75.5.809

Lee, L., Kumar, S., \& Leong, L. C. (1994). The impact of five-month basic military training on the body weight and body fat of 197 moderately to severely obese Singaporean males aged 17 to 19 years. International Journal of Obesity, 18(2), 105-109.

Leibel, R. L., Rosenbaum, M., \& Hirsch, J. (1995). Changes in energy expenditure resulting from altered body weight. New England Journal of Medicine, 332(10), 621-628. https://doi.org/http:// doi.org/10.1056/NEJM199503093321001

Licinio, J., Caglayan, S., Ozata, M., Yildiz, B. O., De Miranda, P. B., O’Kirwan, F., \&..., \& Krauss, $R$. M. (2004). Phenotypic effects of leptin replacement on morbid obesity, diabetes mellitus, hypogonadism, and behavior in leptin-deficient adults. PNAS, 101(13), 4531-4536. https://doi.org/https://doi.org/10.1073/pnas.0308767101

Linton, M. J., Dieppe, P., \& Medina-Lara, A. (2016). Review of 99 self-report measures for assessing well-being in adults: exploring dimen- sions of well-being and developments over time. BMJ Open, 6(7), 1-17. https://doi.org/10.1136/bmjopen-2015-010641

Lutz Slagter, H. A., Dunne, J. D. and R. J. Davidson (2008). Attention regulation and monitoring in meditation. Trends in cognitive sciences. 12 (4): 163-9. doi:10.1016/j.tics.2008.01.005. PMC 2693206. PMID 18329323.

Maglishco, E., (1993). Swimming even faster, California: Mayfield Pub Comp, 249-268.

McArdle, W. D. (198l), Exercise physiology, energy, nutrition and human performance, Philadelphia.

McNerney, J.W. (1978), Help your self, Blue Print, Illinois.

Martínez-González, M. Á., Alfredo Martínez, J., Hu, F. B., Gibney, M. J., \& Kearney, J. (1999). Physical inactivity, sedentary lifestyle and obesity in the European Union. International Journal of Obesity and Related Metabolic Disorders: Journal of the International Association for the Study of Obesity, 23(11), 1192-1201. https://doi.org/http://doi.org/10.1038/sj.ijo.0801049 Maslow, A. H. (1971). The farther reaches of human nature. Penguin.

Maughan, R. J. (2000). Nutrition in sport. IOC Medical Commission Publication.

McArdle, W. D., Katch, F. I., \& Katch, V. L. (2014). Exercise physiology: Nutrition, energy, and human performance (8th ed.). Lippincott Williams \& Wilkins.

McArdle, W. D., Katch, F. I., \& Katch, V. L. (2015). Exercise physiology: Energy, nutrition, and human performance (8th ed.). Wolters Kluwer Health/Lippincott Williams \& Wilkins. https://doi. org/https://doi.org/10.1161/01.STR.25.4.793

McNerney, J. W. (1978). Help your self. Blue Print.

Menerney, W. (1978). Help yourself, İlinois, s5.

Muratl, S., \& Hindistan, İ. E. (2018). Sporda kuvvet antrenmanı (1. Baskı ed.).

Ankara: Spor Yaymevi ve Kitabevi.

Murray, B., \& Kenney, W. L. (2019). Egzersiz fizyolojisi-uygulama kılavuzu (T. Bağırgan, Trans. İkinci Baskı ed.). Ankara: Spor Yayinevi ve Kitabevi.

Myers, J. E., Sweeney, T. J., \& Witmer, J. M. (2000). The wheel of Wellness counseling for Wellness: A 
holistic model for treatment planning. Journal of Counseling \& Development, 78(3), 251-266. https://doi.org/10.1002/j.1556-6676.2000.tb01906.x

Organization, W. H. (2017). Overweight and obesity. WHO: Global Health Observatory (GHO) Data. https://www.who.int/gho/ncd/risk_factors/overweight/en/

Orsini, N., Bellocco, R., Bottai, M., \& Pagano, M. (2006). Age and temporal trends of total physical activity among Swedish women. Medicine and Science in Sports and Exercise, 38(2), 240-245. https://doi.org/10.1249/01.mss.0000185086.19220.b3.

Özdoğan, M (2020). İmmün sistem (bağışılklık sistemi) nedir, nasıl çalışır? Vücudun savunma mekanizması. 22 Kasim 2020 tarih. https://www.drozdogan.com/immun-sistem.

Paker, S. (1989). Sporda beslenme. Erten Basim Yayin.

Palastanga, N., Field, D., \& Soames, R. (1994). Anatomy and human movement: Structure and function (2th ed.). Butterworth-Heinemann. https://doi.org/https://doi.org/10.1016/C2013-004562-8

Pate, R. R., Pratt, M., Blair, S. N., Haskell, W. L., Macera, C. A., Bouchard, C., \& Kriska, A. (1995). Physical activity and public health: a recommendation from the Centers for Disease Control and Prevention and the American College of Sports Medicine. JAMA, 273(5), 402-407. https://doi. $\mathrm{org} / 10.1001 /$ jama.1995.03520290054029

Phelan, M. (1979). Transcendental Meditation. A Revitalization of the American Civil Religion. Archives de Sciences Sociales Des Religions, 48(1), 5-20. http://www.jstor.org/stable/30124703

Pollock, M. L., Foster, C., Knapp, D., Rod, J. L., \& Schmidt, D. H. (1987). Effect of age and training on aerobic capacity and body composition of master athletes. Journal of Applied Physiology, 62(2), 725-731. https://doi.org/10.1152/jappl.1987.62.2.725.

Porgalı Zayman, E. (2020). Mikrobiyota nedir? Dünü, bugünü, yarmı.

Mikrobiyata ve Psikiyatrik Hastaliklar, 1, 1-5.

Powers, S. K., \& Howley, E. T. (2011). Exercise physiology: Theory and application to fitness and performance (8th ed.). McGraw-Hill Higher Education.

Rainforth, M. V, Schneider, R. H., Nidich, S. I., Gaylord-King, C., Salerno, J. W., \& Anderson, J. W. (2007). Stress reduction programs in patients with elevated blood pressure: a systematic review and meta-analysis. Current Hypertension Reports, 9(6), 520-528. https://doi.org/10.1007/ s11906- 007-0094-3

Reardon, C. L., Hainline, B., Aron, C. M., Baron, D., Baum, A. L., Bindra, A., ... \& Derevensky, J. L. (2019). Mental health in elite athletes: International Olympic Committee consensus statement (2019). British Journal of Sports Medicine, 53(11), 667-699.https://doi.org/10.1136/bjsports2019- 100715.

Rivera, JLGde (2001). Autogenic análisis: The tool Freud was looking for. International J. Psychotherapy, 6, 67-76

Rivera, JLGde (1997)..Autogenic psychotherapy and psychoanalysis. In: "The body in Psychotherapy", pp. 176-181. Editor: J. Guimón. Karger, Basilea.Road, H., (Çev.). (1992). Sağlıklı beslenme rehberi. Singapore: Copy Right Thebe,

Romero-Corral, A., Montori, V. M., Somers, V. K., Korinek, J., Thomas, R. J., Allison, T. G., \& Lopez-Jimenez, F. (2006). Association of bodyweight with total mortality and with cardiovascular events in coronary artery disease: a systematic review of cohort studies. Lancet, 368 (9536), 666678. https://doi.org/https://doi.org/10.1016/S0140-6736(06)69251-9

Sallis, J. F., \& Owen, N. (1998). Physical activity and behavioral medicine. In J. Sallis \& N. Owen (Eds.), Behavioral medicine and health psychology (Vol. 3). Sage Publications.

Sallis, J. F., \& Owen, N. (1998). Physical activity and behavioral medicine (Vol. 3.) SAGE publications.

Senger, E. (1987). Beslenme ve diyet. Beta Yayıncilik.

Seran, B., Akbulut, A., Pekel, H.A., Aydos, L. (2021). Covid- 19 salgınının çocuk ve gençlerin hareket, oyun davranışları ve fiziksel aktivitenin üzerindeki etkileri. 4. Uluslararası Herkes İçin Spor 
Kongresi. (ss 213-215). Ankara. https://sfasummit.org/tr/

Sharkey, B.T., (1990), Physiology of Fitness, The Canadian Experience, The Journal of Sports Medicine and Physical Fitness, $45(4), 230$.

Sharkey, B. J. (1991). New dimensions in aerobic fitness. Human Kinetics.

Söyleyıcı Z. S. and Zorba, E. (2017). Examining the healthy lifestyle behaviors of university students. European Journal of Physical Education and Sport Science, 3(7), 67-76., Doi: 0.5281/ zenodo.821443 (Yaym No: 3926239)

Spitzer, R. L., Kroenke, K., Williams, J. B., \& Löwe, B. (2006). A brief measure for assessing generalized anxiety disorder: the GAD-7. Archives of internal medicine, 166 (10), 1092-1097. https:// doi.org/10.1001/archinte.166.10.1092.

Stanković, M., Radovanović, D. (2012) Oxidative stress and physical activity. Sportlogia, 8 (1), 1-11

Stunkard, A. J., Foch, T. T., \& Hrubec, Z. (1986). A twin study of human obesity. Jama, 256(1), 51-54. https://doi.org/10.1001/jama.1986.03380010055024

Stunkard, A. J., Sørensen, T. I., Hanis, C., Teasdale, T W Chakraborty, R., Schull, W. J., \& Schulsinger, F. (1986). An adoption study of human obesity. New England Journal of Medicine, 314(4), 193-198. https://doi.org/10.1056/NEJM198601233140401

Stuart, E. M., \& Goldberg, M. (1993). The Wellness book. The Comprehensive Guide to.

Şenışık, S. Ç. (2015). Egzersiz ve bağıısılklık sistemi. Spor Hekimliği Dergisi, 50, 11-20. 1-50.

Tayler, I., Sutton, S. (1974), Age of the Runner. P. O. Box, Mountain view.

Tenenbaum, G. (2018). Psychosocial Measurement Issues in Sport and Exercise Settings. In Oxford Research Encyclopedia of Psychology.

Türkmen, M., (2018). Beden terbiyesi erken dönem türk spor politikalarmın sosyo-politik temelleri. Ankara: Spor Yayınevi, The Challenge of Obesity in the WHO European Region And The Strategies For Response, Ed. Francesco Branca, Haik Nikogosian ve Tim Lobstein, WHO, Denmark, 2007.

Thomas, J. R., Nelson, J. K., \& Silverman, S. J. (2015). Research methods in physical activity. Human Kinetics.

Tunca R. İpek E. (2016). Yaşlanmanın biyolojisi. Animal Health Prod and Hyg, 5(2), 467 - 471.

Turna, G., Kıllı̧, N., Sarı, Z. Y. S. (2011). Ehrlichasit solid tümör modeli oluşturulmuş farelerde ymussipyleus ve Taurini karaciğer MDA, GSH, AOPP düzeylerine ve SOD aktivitesine etkileri, Türkiye Klinikleri Journal of Medical Sciences, 31 (5), 1153-1159.

Türkiye Halk Sağlı̆̆ı Genel Müdürlüğü,2017.

Yildız G. M., Aras S., Duman C. D. (2010). Telomerin yaşlanma üzerindeki etkisi. Türkiye Hijyen ve Deneysel Biyoloji Dergisi, 66(4), 187-195.

UK Sport. http://www.uksport.gov.uk/news/2018/10/10/positive-mental- health-environment-acros solympic-and-paralympic-sport. Accessed 09 Aug 2019. United States of America, (198l), "How to Keep for Life" 6. Edition, USA, New York.

University of Wisconsin-Madison (2008, March 27). Compassion Meditation Changes The Brain. ScienceDaily. Retrieved February 1, 2014, from http://www.sciencedaily.com/releases/2008/03/080326204236.htm

Van der Ploeg, H. P., Merom, D., Corpuz, G., \& Bauman, A. E. (2008). Trends in Australian children traveling to school 1971-2003: Burning petrol or carbohydrates? Preventive Medicine, 46(1), 60-62.

Vandevelde, S., Van Keer, H., Schellings, G., \& Van Hout-Wolters, B. (2015). Using think-aloud protocol analysis to gain in-depth insights into upper primary school children's self-regulated learning. Learning and Individual Differences, 43, 11-30. https://doi.org/10.1016/j.lindi f.2015.08.027.

Vanhees, L., Lefevre, J., Philippaerts, R., Martens, M., Huygens, W., Troosters, T., \& Beunen, G. (2005). How to assess physical activity? How to assess physical fitness? European Journal of Cardiovascular Prevention and Rehabilitation, 12(2), 102-114. https://doi.org/10.1097/01. hjr.0000161551.73095.9c. 
Vuori, I., P, F., Svoboda, B., Patriksson, G., Andreff, W., \& Weber, W. (1995). The significance of sport for society: health, socialisation, economy. Council of Europe.

Vuori, I., Fenten P., (1996), Health, Significanc of Sport For Society, November, Sofia, ss. 1-8.

Wellness Way of Life by Debbie Powers and Gwen Robbins (2008, Paperback)

Wadden, T. A., Berkowitz, R. I., Womble, L. G., Sarwer, D. B., Phelan, S., Cato, R. K., \& Stunkard, A. J. (2005). Randomized trial of lifestyle modification and pharmacotherapy for obesity. New England Journal of Medicine, 353(20), 2111-2120. https://doi.org/10.1056/NEJMoa050156

Watts, A. (2009). "11_10-4-1 Meditation." Eastern Wisdom: Zen in the West \& Meditations. The Alan Watts Foundation. MP3 CD. @4:45

Wellness Way of Life by Debbie Powers and Gwen Robbins (2008, Paperback). Werner, W. K. H., Sharon, A. H., Cherie, H., \& Amber, F. (2015). Lifetime Physical Fitness \& Wellness: A personalized programme (15th ed.). Thomson

Wadsworth.

WHO. (2010). Global recommendations on physical activity for health. World Health Organization.

Williams C.,Harageones E. G., Johnson D., Smith C., (1999). Personal fitness looking good feeling good. Iowa: Kendall/Hunt Publishing Company, 81- 98 Williams, C. S., Harageones, E. G., Johnson, D. J., \& Smith, C. D. (2000). Personal fitness: Looking good-feeling good: Student activity handbook (4th ed.). Kendall Hunt Pub Co.

Williams, C. S., Harageones, E. G., Johnson, D., \& Smith, C. D. (2004). Personal Fitness: Looking Good Feeling Good (5th ed.). Kendall Hunt Publishing.

Wong, M.-L. (2004). Phenotypic effects of leptin replacement on morbid obesity, diabetes mellitus, hypogonadism, and behavior in leptin-deficient adults. Proceedings of the National Academy of Sciences, 101(13), 4531- 4536. http://doi.org/10.1073/pnas.0308767101

Wynne, K., Park, A. J., Small, C. J., Patterson, M., Ellis, S. M., Murphy, K. G., ..., \& Bloom, S. R. (2005). Subcutaneous oxyntomodulin reduces body weight in overweight and obese subjects: A double-blind, randomized, controlled trial. Diabetes, 54(8), 2390-2395. https://doi.org/ http://doi.org/10.2337/diabetes.54.8.2390.

Yaman N. ve Zorba, E. (2016). Sporda kronolojik yasa göre yapılan yetenek seçiminde, biyolojik olgunluğun cinsiyete göre motor becerilere etkisi. Uluslararası Hakemli Akademik Spor Sağlı ve Tip Bilimleri Dergisi, (21), 94-108. Yilmaz, C. (1995). Obezite. Nobel Tip Kitapevleri.

Yusuf, S., Hawken, S., Ônpuu, S., Bautista, L., \& Franzosi, M. (2005). Obesity and the risk of myocardial infarction in 27000 participants from 52 countries: a case-control study. Lancet, 336 (9497), 1640-1649. https://doi.org/10.1016/S0140-6736(05)67663-5 B

Ziyagil, M. A. ve Zorba, E., (1995), Sporda beslenme ders notları. Trabzon.

Zohman, R. L. (1980). Exercise your way to fitness and heart. American heart association.

Zorba, E. (1989). Development of an equation to predict the percent body fat of Turkish wrestlers in Ankara through skinfold method. Middle East Technical University, Ankara.

Zorba, E. (1990). Milli takım düzeyindeki türk güreş̧̧ileri için derialtı yağ kalınlığı denklemi geliştirilmesi. Marmara University, İstanbul.

Zorba, E., Ziyagil, M. A. (L995), Vücut kompozisyonu ve ölçüm metotları, gen yayınları, Trabzon. "endüstride bedeni aktivitenin önemi", marmaranın sesi dergisi, sayı, 4l, s.23.

Zorba, E., (1995). Sağlığınız ve egzersiz. Ankara: Gen Matbaasl,

Zorba E., (1999). Herkes için spor ve fiziksel uygunluk. Ankara: Neyir Matbaası.Zorba, E. (2001). Fiziksel Uygunluk. Ankara: Gazi Yayınevi, Zorba, E., Et Al., (2005). 65-85 yaş arasındaki yaşlllarda 10 haftalı antrenman programının bazı fiziksel uygunluk parametrelerine etkisinin Araştırılması. F.Ü. Sağllk Bil. Dergisi, 18(4), 229-234.

Zorba, E., (2002), Muğla üniversitesi öğretim elemanları ve idari görevde çalışan personelin hayat tarzı ve aktivite düzeyleri, Muğla Üniversitesi Araşttrma Projesi, Muğla: MÜ MatbaasıZorba E.,(2002). Muğla üniversitesi erkek öğrencilerinin zararl alışkanlıklara sahip olan ve olmayanların fiziksel uygunluk ve antropometrik özellikleri ile spor yapma alışkanlıklarının karşılaştırılması, Muğla: Muğla Üniversitesi BAP Projesi Yöneticisi, M.Ü. Matbaası. 
Zorba, E., et al., (2005). 65-85 Yaş arasındaki yaşlilarda 10 haftalik antrenman programının bazı fiziksel uygunluk parametrelerine etkisinin araştırılması. F.Ü. Sağlık Bil. Dergisi, 18(4), 229-234.

Zorba, E. (2006). Yaşam boyu spor. Ankara: Nobel Yayın Evi.

Zorba, E. (2006). Vücut Yapısı ve Ölçüm Yöntemleri, Şişmanlıkla Başa çıkma. Ankara: Morpa Kültür Basım Evi

Zorba, E. (2014). Yaşam boyu spor (Geliştiril). Atalay Matbaacilik.

Zorba, E. (2015). Herkes için Yaşam Boyu Spor. Firat Matbaacılik.

Zorba, E., \& Saygin, Ö. (2017). Fiziksel aktivite ve fiziksel uygunluk (geliștiril).

Perspektif Matbaacilik.

Zorba E., Bayrakdar, A., Gönülates, S., Sever, O. (2017). Analysis of the level of life quality of university students. The Online Journal of Recreation and Sport, 6(1), 1-16., Doi: 10.22282 ojrs.2017.5(Yayin No: 3690807). 